\title{
Türkiye Paralimpik Takımlar Ağız-Diş Sağlığı Profili
}

\section{Mouth-Dental Health Profile of The Turkish Paralympic National Team}

\author{
ORIIJINAL ARAŞTIRMA/ \\ ORIGINAL RESEARCH \\ Osman HAMAMCILAR $^{1 *}$
Tuğba KOCAHAN $^{2}$
Adnan HASANOĞLU
}

${ }^{1} \mathrm{GSB}$, Sağlık İşleri Dairesi Başkanlı̆̆ https://orcid.org/0000-0002-1589-871X

${ }^{2} \mathrm{GSB}$, Sağlık İşleri Dairesi Başkanlığı, Ankara. https://orcid.org/0000-0002-0567-857X

${ }^{3} \mathrm{GSB}$, Sağlık İşleri Dairesi Başkanlığı, Ankara https://orcid.org/0000-0003-4486-5092
Yayın Bilgisi

Gönderi Tarihi: 26.12.2017

Kabul Tarihi: 24.05.2019

Online Yayın Tarihi: 30.06.2019

\section{$\ddot{\mathbf{O z}}$}

Rio 2016 Paralimpik Oyunlarına hazırlanan Türk sporcularının ağız-diş sağlığı profilini göstermek ve koruyucu diş hekimliği hizmetlerini arttırmaya yönelik önlemler almaktır. Çalışmamıza Rio 2016 Paralimpik Oyunlarına hazırlanan judo, atletizm ve erkek golball branşlarından oluşan görme engelli $n=17$ (\% 24) sporcu; okçuluk, basketbol, yüzme, tenis, masa tenisi branşlarından oluşan bedensel engelli $n=43(\% 60,5)$ sporcu ve işitme engelli tekvando branşından $\mathrm{n}=11(\% 15,5)$ sporcu katıldı. Sporcuların çürük (D), kayıp $(\mathrm{M})$, restore diş $(\mathrm{F})$ indeksi (DMF-T) ve toplumda periodontal tedavi gereksinim indeksi (CPITN) değerlendirmeleri, Dünya Sağlık Örgütü (DSÖ) kriterlerine göre yapıldı. Sporcuların sahip oldukları çürük, kayıp ve restore diş sayısal değerleri ile yaş Paired-Samples T Testi istatiksel analiz yöntemi ile istatiksel olarak değerlendirildiğinde; $\mathrm{D}, \mathrm{M}$ ve F sayısal değeri ile yaş arasında, istatiksel olarak anlamlılık görüldü $(\mathrm{p}<0.05)$. Cinsiyet ile diş hastalığı karşılaştırıldığında, D, M ve $F$ sayısal değerleri her iki cinsiyette istatiksel olarak anlamlıydı $(\mathrm{p}<0.05)$; cinsiyet ve periodontal doku hastalığı arasındaki ilişkide her iki cinsiyette istatiksel olarak anlamlı bulundu $(\mathrm{p}<0,05)$. Engelli sporcuların sahip oldukları diş ve dişeti hastalık oranları DSÖ 2020 hedef değerlerinin üzerindeydi. Buna rağmen sporcu grubunun diş kaybından daha çok dişin tedavisine yönelik eylemlerde bulunduğu görüldü. Koruyucu diş hekimliği hizmetini arttırmak için engelli sporculara yılda iki kez ağız-diş sağlığı kontrolü yapılmalı ve ağı-diş sağlı̆̆ının sporcu sağlığı üzerine etkileri hakkında eğitimler düzenlenmelidir.

Anahtar Kelimeler: Engelli sporcu, DMF-T, periodontal hastalı.

\begin{abstract}
To display the profile of oral and dental health of Turkish athletes preparing for Rio 2016 Paralympic Games and to take measures to improve preventive dentistry services. $n=17$ ( $24 \%$ ) visually impaired athletes of judo, athletics and goalball (men) brances; $\mathrm{n}=43(60.5 \%)$ athletes with physical disabilities of coarchery, basketball, swimming, tennis, table tennis branches and $\mathrm{n}=11$ (\% $15,5)$ athletes with hearing impaired taekwondo branches preparing for Rio 2016 Paralympic Games participated in our study. The evaluations of athletes' decay (D), missing (M), filled (F) teeth (DMF-T) index and of community periodontal treatment need index (CPITN) have been made according to the World Health Organization (WHO) criteria. In statistical evaluation realized through pairedsamples t-test statistical analysis method, there was a statistically significance between the athletes' $\mathrm{D}, \mathrm{M}$ and $\mathrm{F}$ numerical values and the age $(\mathrm{p}<0.05)$. In comparison of gender and dental disease, D, M and F numerical values were statistically significant for both genders $(p<0.05)$; the relation between gender and periodontal tissue disease was found statistically significant $(\mathrm{p}<0.05)$. Dental and periodontal disease rates of disabled athletes were above the WHO's 2020 target values. However, it was seen that the athletes' group had been actively involved in tooth treatment rather than tooth loss. In order to increase the provision of preventive dentistry, disabled athletes should have oral and dental health check twice a year and education on the impact of oral-teeth health on the health of athletes should be organized.
\end{abstract}

Key words: Disabled athlete, DMF-T, periodontal disease.

\footnotetext{
"Sorumlu yazar: Osman Hamamcılar, osman_hamamcilar@yahoo.com.tr
} 


\section{GíRiş̧}

Dünya Sağlı Örgütü (DSÖ) sağlı̆ğ; "sadece hastalıklardan ve mikroorganizmalardan korunma değil, bir bütün olarak fiziki, ruhi ve sosyal açıdan iyi olma hali" olarak açıklamıştır (Külekçi, 2009). Hastalık ve mikroorganizmalardan korunma, ağız ve diş sağlığını da içine alarak sağlık bütünlügünü ortaya koymaktadır. Günümüzde ağız ve diş sağlığındaki ortaya çıkan hastalıklar hemen hemen tüm toplumların mücadele ettiği bir alandır. Gerek lokal olarak ağız-diş hastalıklarının yarattığı problemler, gerekse de ağız-diş hastalıklarının yaratabileceği ikincil enfeksiyonlar birey sağlığını tehdit edebilmektedir.

DSÖ, ağız-diş sağlığı ve hastalığına ait epidemiyolojik verilerin toplanmasının birincil derecede önemli olduğunu bildirmiştir. Bu verilerin toplanmasında dünyada en yaygın kullanılan indekslerden biri (D) çürük, (M) kayıp ve (F) dolgulu diş sayısı sayısını bildiren DMFT indeks değeridir. $\mathrm{Bu}$ indeks DSÖ tarafindan toplumdaki diş çürüğü ölçümü ve karşılaştırılması için tavsiye edilmektedir (Aggerryd, 1983; Koser ve Nalçac1, 2011). Topluluğun çürüğe yatkınlığ1 veya çürüğün görülme yüzdesi de "Çürük Sıklık Değeri (Ç.P.D)” olarak hesaplanır ve bildirilir. Bu iki gösterge bir topluluğun diş sağlığını en güzel ifade eden indekslerdir.

Ağız ve diş sağlığının bozulması "mikrobiyal dental plak" ile başlar. Mikrobiyal dental plak diş yüzeyine yapışarak, yapısında oluşturduğu bakterilerin salgıladığı toksinler aracılığı ile ağız sağlığının bozulmasına sebep olur. Diş yüzeyinde gelişen "mikrobiyal dental plak" ağız-diş sağlığını bozan etiyolojik sıralamada ilk faktör kabul edilse de; cinsiyet, ırk, alışkanlıklar, yaş, sistemik hastalıkların varlığı, sosyo-ekonomik kültürel durum (Altun, 2005), beslenme akışkanlığı ve sıklığı (ara öğün ve fast food)(Linea ve Former, 2008; Nadio ve Myburgh, 2008), flor ve benzeri koruyucu ajanların günlük hayatta kullanımının (Almerich-Silla ve Montiel-Company, 2007), ağız-diş sağlı̆̆ı üzerine olan etkileri gösterilmiştir.

Diş çürüğü ve periodontal hastalıklar bilinen en yaygın kronik hastalıklardır ve birçok ülkenin ağız sağlığı problemleri olmaktadırlar. Kardiyovasküler hastalıklar, diyabet ve düşük doğum ağırlı̆̆ı gibi birçok sağlık problemleriyle beraber görülebilen bu hastalıklar diş kayıplarının öncelikli nedenlerinden biridir. Günümüzde okul çağına ulaşmış çocukların \%60-90'nı hala diş çürüğü etkisi altındadır (Susan ve ark, 2007) . 2004 yılında Türkiye’de yapılan bir araştırmada 1215 yaş için çürük diş görülme yüzdesinin \%61,1-\%61,2 değerinde olduğu, dişsizler dişarıda 
bırakıldığı zaman bu yüzdenin 35-44 yaş için \%75,8 olduğu bildirilmiştir. Aynı çalışmada diş kaybının 12 yaş için \%7,9, 15 yaş için \%16,2 olduğu yaş ilerledikçe diş kaybının arttı̆̆ ve 35-44 yaş için bu oranın \%89,3 olduğu rapor edilmiştir (Doğan ve Gökalp, 2008). Farklı bir çalışma Hindistan'da yapılmış ve daimi birinci büyük azı diş çürüğü görülme yüzdesinin 14-17 yaş için \%62.6, 18-25 yaş için \%67.6'ya çıktığı, 26-35 yaş bireylerde diş kaybıyla birlikte yüzde oranın düşerek \%59.7 ve 36 yaş ve üstü bireylerde ise \%51 olduğu tespit edilmiştir (Ünlü, Şener ve Karabekiroğlu, 2014).

Periodontal hastalıklar, dişetinde gelişen infeksiyonun dişeti bağ dokusu, periodontal ligament ve alveol kemiğine ilerlemesiyle dişin destek dokularında yıkım ve bunun sonucunda diş kaybının gerçekleştiği, kronik enflamatuvar hastalıklardır. Periodontal hastalıkların önemli ve öncelikli etyolojik faktörü patojen mikroorganizmalardır. Bu mikroorganizmalar, biyofilm yapısındaki kompleks polisakkarit bir matriks içinde bulunurlar. Periodontal hastalıkların başlamasında ve gelişmesinde rol oynayan periodontal patojenler ve onların ürettiği toksinler konak savunmasını uyarır. Gelişen konak cevabı, bir yandan periodontal dokuları lokal mikrobiyal saldırıya karşı koruyarak doku içerisinde patojen mikroorganizmaların yayılmasını önlerken, diğer yandan çevresindeki hücrelere ve ekstraselüler matrikse zarar vererek dişeti, periodontal ligament, sement ve alveol kemiğinde hasar ve kayba neden olur (Kinane ve Attstrom, 2005; Slots, 2002). Periodontal hastalıkların en yaygın ve önemli iki tipi vardır. Bunlar 1) gingivitis; diş etinin kızarık enfekte ve kanamalı fakat ataçman kaybının daha başlamadığı hastalıklı halidir. 2) Periodontitis; ilerlemiş diş eti hastalığı olup, ataçman kaybının görüldüğü ve ileri zamanda kendiliğinden dişlerin sallanması ile diş kaybının gelişebildiği hastalık tipidir.

Türkiye'de yapılan bir çalışmaya göre, engelli olmayan 20-27 yaş aralı̆̆ına sahip erkeklerde gingivitis görülme oranının \%65.6, periodontitis görülme oranının ise $\% 29.8$ olduğu bildirilmiştir (Şahin ve ark., 2009). DSÖ'nün yapmış olduğu hesaplamalara göre engelli bireyler, gelişmiş ülkelerin \%10' unu, gelişmekte olan ülkelerin de \%12' sini oluşturmaktadır. Ülkemizde Devlet İstatistik Enstitüsü tarafından 2002 yılında gerçekleştirilen Türkiye Engelliler Araştırmasının verilerine göre ülkemizdeki engelli nüfus oranının \%12.29 (erkeklerde \%11.10, kadınlarda \% 13.45) olduğu rapor edilmiştir. Engelli nüfusun $\% 1.25$ 'ini ortopedik engelliler $\% 0.38$ ' ini dil ve konuşma engelliler, $\% 0.60$ 'ını görme engelliler, $\% 0.37$ ' sini işitme engelliler, $\% 0.48$ ' ini zihinsel engeliler oluşturmaktadır (Sarı, Özmen, Koyuturk ve Tokay, 2012). 
Yapılan farklı çalışmalarda engelli bireylerin ağız-diş sağlığının yetersizliği öne çıkmıştır. Nitekim 14-17 yaşları arasındaki görme engelli, işitme engelli, bedensel engelli, konuşma engelli, zihinsel engelli ve sağlıklı toplam 750 yetişkin genç birey ile yapılan çalışmada, engelli türüne bakılmaksızın tüm grupların plak miktarı, çürük ve periodontal hastalıklar oranının sağlıklı bireylere göre belirgin bir artış gösterdiği bildirilmiştir (Ameer ve ark., 2012). Engelli sporcular, özel ilgi ve çalışma isteyen sporcu grubudur. Yllın büyük bir çoğunluğunu antrenman ve müsabaka ile geçiren sporcuların, enerji metabolizmasını aktif durumda tutabilmek için her sporcu gibi özel diyet programına ihtiyaçları vardır. Bu durum kendi içinde bir tehlikeyi de getirmektedir. Uygulanan yüksek karbonhidratlı öğün diyetleri ve ara öğünlerin tercih edilmesi beraberinde eşlik eden oral-hijyen yetersizliği, diş çürük ve periodontal hastalık oluşum riskini de arttırmaktadır.

Ağız-diş sağlığı, genel sağlığın bir parçasıdır ve bozulduğunda sporcunun genel sağlığı ve yaşam kalitesini olumsuz etkilediği gibi, spor performansını da olumsuz etkilemektedir. Periodontal veya diş hastalıklarının sporcu performansına olumsuz etkilerine yönelik çalışmalar mevcuttur. Nitekim, yüzücülerin performansı ile diş çürüğü arasında düşükte olsa bir ilişki olduğu bildirilmiştir (Tieri, Martinelli ve Tripodi 2016). Ayrıca yüksek çürük skorunun ve periodontal hastalıkların performansı olumsuz etkilediği ve sporcu kas, tendon hatta kemik yaralanmaları ile ilişkili olabileceği raporlanmıştır (Gay-Escoda ve ark., 2011). Bu çalışmanın amacı, paralimpik oyunlara katılan engelli sporcuların ağız-dişs sağlığı profilini göstermek, koruyucu diş hekimliği hizmetini arttırmaya yönelik önlemler almak ve sporcunun spor performansına katkıda bulunmaktır.

\section{YÖNTEM}

Bu çalışma, Gençlik ve Spor Bakanlığı Spor Genel Müdürlüğü Sağlık İşleri Dairesi Başkanlığı’na bağlı olan ve Ankara'da bulunan “Türkiye Olimpiyat Hazırlık Merkezi” (TOHM) içindeki "Sporcu Ağız-Diş Sağlığı Kliniğinde" bünyesinde, Mart-Temmuz 2016 tarihleri arasında gerçekleşti. Çalışmamız sporculara uygulanan rutin muayene standartları içindeydi. Sporcu grubuna Helsinki Deklarasyonu prensiplerine uygun olarak "Bilgilendirme Onam" ve "Genel Onam" formları okutularak imzalattırıldı. Sporcuların oral hijyen alışkanlıklarını belirlemek için anket uygulandı. DMF-T ve CPITN değerlendirmeleri DSÖ kriterlerine göre, aynı diş hekimi tarafından ayna, sond ve presel kullanılarak yapıldı (Saraçoğlu, Kümbüloğlu, Hatipoğlu ve User, 2007; Şahin ve ark., 2009). 
Çalışmamıza 2016 Rio Paralimpik Oyunları Türkiye Paralimpik Milli Takımı olarak görme engelli (\% 23.9) $\mathrm{n}=17$ sporcu (Judo=5, Golball=6, Atletizm=6), bedensel engelli (\% 60.5) $\mathrm{n}=43$ sporcu (Okçuluk=7, Basketbol=15, Yüzme=8, Tenis=2, Masa tenisi=11), İşitme engelli (\% 15.4) $\mathrm{n}=11$ sporcu (Teakwando=11) toplamda $\mathrm{n}=71$ sporcu katıldı. Çalışmaya katılan sporcular 16-42 yaş aralı̆̆ına sahip yaş ortalaması $25,69 \pm 7,10$ olup, kadın (\% 26.7) $n=19$ sporcu, erkek (\% 73.3) $\mathrm{n}=52$ sporcuydu (Tablo 1$)$.

Tablo 1. Sporcuların dağ 11 เmı

\begin{tabular}{cccc}
\hline Sporcu & $\begin{array}{c}\text { Bedensel } \\
\text { Engelli }\end{array}$ & $\begin{array}{c}\text { Görme } \\
\text { Engelli }\end{array}$ & $\begin{array}{c}\text { İşitme } \\
\text { Engelli }\end{array}$ \\
\hline $\begin{array}{c}\text { Erkek } \\
(\mathbf{\% 7 3 , 2 )}\end{array}$ & 31 & 16 & 5 \\
$\begin{array}{c}\text { Kadm } \\
(\mathbf{\% 2 6 , 8})\end{array}$ & 12 & 1 & 6 \\
Toplam & 43 & 17 & 11 \\
\hline
\end{tabular}

Bedensel engelli sporcu sayısı diğer engelli sporcu sayısından 2,5 ve 4 kat fazladır. Dişlerin sağlı̆̆ının değerlendirilmesinde; çürük (D), çürük nedeniyle çekilmiş (M) ve çürük nedeniyle dolgu yapılmış (F) dişlerin toplamının, muayene olan kişi sayısına bölünmesiyle elde edilen (T) kriterlerinden oluşan ve DMF-T (daimi dişler) indeksinden faydalanıldı. Bu değerler sonucunda sporcu grubunda kişi başına düşen hastalıklı diş sayısı "DMFT indeks değeri" ve grubun çürük yayılım oranı "Ç.P.D” bulundu.

Periodontal sondalama derinliği DSÖ periodontal sondu ile ölçüldü ve sporcunun CPITN skoru olarak kaydedildi. Periodontal durum CPITN skorlarına göre şu şekilde tanımlandı: 0: Sağlıklı; 1: Sondalamayla kanama; 2: Supra veya subgingival diştaşı/taşkın dolgu kenarları; 3: Cep derinliği 4-5 mm; 4: Cep derinliği > $5 \mathrm{~mm}$ (Tablo 2).

Tablo 2. Periodontal skor ölçeği

\begin{tabular}{cl}
\hline & Periodontal durum $(\mathbf{C P I})$ \\
\hline Skor & Durum \\
\hline 0 & Sağlıklı \\
1 & Kanama \\
2 & Diştaş1 \\
3 & Cep 4-5 $\mathrm{mm}$ \\
4 & Cep > $5 \mathrm{~mm}$ \\
\hline
\end{tabular}

Sporcular beş ayrı periodontal skor ile değerlendirildi. 
Sporcuların oral-hijyen alışkanlıkları, diş fırçalama sıklıkları ve diş hekimine ziyaret sıklıkları muayene sırasında, muayene formunda bulunan mini anket ile değerlendirildi. Araştırma kapsamındaki tüm sporculardan sayımla belirlenen değişkenler için sayı ve yüzde, ölçümle belirlenen değişkenler için ise ortalama \pm standart sapma olarak tanımlayıcılar elde edildi. İstatistiksel analizler için MS-Excel ve SPSS for Windows Ver.14.0 (SPSS Inc., Chicago, IL, USA) programları kullanıldı. Paired-Samples $T$ testi istatiksel analiz yöntemine göre tüm karşılaştırmalarda $p<0.05$ düzeyi anlamlı farklılığın göstergesi olarak kabul edildi.

\section{BULGULAR}

Yapılan muayene sonucu araştırmamızda bedensel engelli milli takımından 23 sporcuda 46 çürük, görme engelli milli takımından 11 sporcuda 23 çürük, işitme engelli milli takımında ise 3 sporcuda 3 çürük olmak üzere toplamda 72 çürük diş bulundu (Tablo 3). Yine bedensel engelli milli takımlarda 48 eksik diş, görme engelli milli takımlarda 7 eksik diş, işitme engelli milli takımda 10 eksik diş olmak üzere toplamda 65 eksik veya çekilmiş diş tespit edildi (Tablo 3).

Dolgu ve/veya kron kaplama yapılmış diş dağılımı da; bedensel engelli milli takımlar 123 diş, görme engelli milli takımlar 17 diş, işitme engelli milli takım 23 diş olmak üzere toplamda 163 dişin tedavi görmüş olduğu belirlendi (Tablo 3). Sporcuların engellilik durumlarına göre sahip oldukları diş hastalıkları değerlendirildiğinde; bedensel engelli sporcularda kadın - erkek sayısal oranında $\mathrm{D}$ ve $\mathrm{F}$ değeri yaklaşı $1 / 2$ iken, $\mathrm{M}$ değerinde bu oran yaklaşık 1/4 olarak bulundu. İşitme engelli sporcu grubunda da D, M, ve F değerleri oransal olarak bedensel engelli sporcu oransal değerine yakındı. Görme engelli sporcularda ise D, M, ve F değerlerinin kadın - erkek sayısal oranıyla karşılaştırıldığında sırasıyla 1/10, 0/7 ve 1/16 gibi yüksek bir oransal aralık bulundu (Tablo 3).

Tablo 3. Ağız-diş muayene sonucu

\begin{tabular}{lrrrrrrrrr}
\hline & D: & \multicolumn{2}{c}{ Çürük diş } & \multicolumn{1}{c}{ M: } & \multicolumn{2}{c}{ Eksik diş } & \multicolumn{1}{c}{ F: } & \multicolumn{2}{c}{ Restore diş } \\
\hline & Bed. & Görme & İşit. & Bed. & Görme & İşit. & Bed. & Görme & İşit. \\
Eng. & Eng. & Eng. & Eng. & Eng. & Eng. & Eng. & Eng. & Eng. \\
Kadın & 31 & 21 & 1 & 39 & 7 & 7 & 81 & 16 & 16 \\
Toplam & 15 & 2 & 2 & 9 & 0 & 3 & 42 & 1 & 7 \\
\hline
\end{tabular}

Sporcuların engellilik durumuna göre DMF değerleri. 
Elde edilen bu veriler doğrultusunda paralimpik takımdan 34 sporcuda (erkek 25 - kadın 9) toplam 72 çürük diş, 30 sporcuda toplam (erkek 23 - kadın 7) 65 eksik diş ve 40 sporcuda toplam (31 erkek - 9 kadın) 163 dolgulu diş görüldü (Grafik 1).

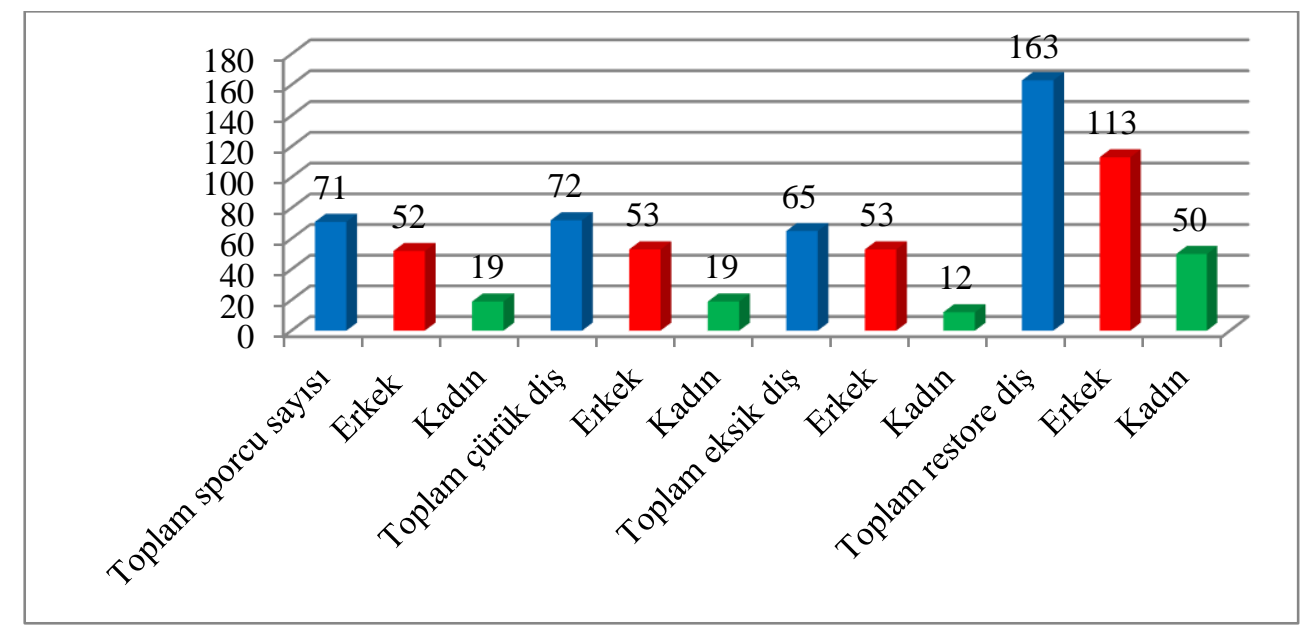

Grafik 1. Cinsiyete göre D,M ve F dağılımı.

Sporcuların sahip oldukları D,M ve F sayısal değerler ile yaş istatiksel olarak değerlendirildiğinde; D, M ve F sayısal değer ile yaş arasında istatiksel olarak anlamlılık görüldü $(p=0,000$ ve $p<0,05$ ). Cinsiyet ile $D, M$ ve $F$ karşılaştıııldığında, sporcularda $D$ sayısal değeri için $\mathrm{p}=0,000$, M sayısal değeri için $\mathrm{p}=0,001$ ve $\mathrm{F}$ sayısal değeri için $\mathrm{p}=0,000$ bulundu. Ortaya çıkan değer istatiksel olarak anlamlıydı $(\mathrm{p}<0,05)$.

Sporcuların DMF-T indeks değeri 4.2 ve Ç.P.D \% 47,8 (erkek \% 35,2 - kadın \% 12,6) olarak bulundu. Ç.P.D erkek sporcularda kadın sporculara göre sporcu sayısal değerlerine paralel olarak yaklaşık 3 kat yüksekti. Sporcu grubu sahip olduğu DMF-T değeri ile DSÖ’nün 2020 hedef değeri olan DMF-T $<1$ değerinden uzaktı.

Periodontal muayene sonucunda 71 sporcudan 37 'sinde $(\% 52,1)$ skor=1 ve 2'ye denk düşen (kanamalı + diş taşı) dişeti hastalığı (akut gingivitis) belirlendi. Periodontal hastalığın cinsiyete göre görülme yüzdesi; erkek sporcularda $n=29(\% 78,4)$ ve kadın sporcularda $n=8(\%$ 21,6) olduğu görüldü. Sporcuların cinsiyetlerine göre oranları kadın/erkek $=1 / 3$ iken periodontal hastalığa sahip cinsiyet oranı kadın/erkek $=1 / 4$ 'tü (Grafik 2). Cinsiyet ve periodontal doku hastalığı arasında istatiksel olarak anlamlı bir ilişki görüldü $(p=0.004, p<0,05)$. Yaş ile periodontal 
hastalık istatiksel olarak karşılaş̧ırılldığında, $\mathrm{p}=0,000$ bulundu ve istatiksel olarak anlamlılık görüldü $(\mathrm{p}<0,05)$.

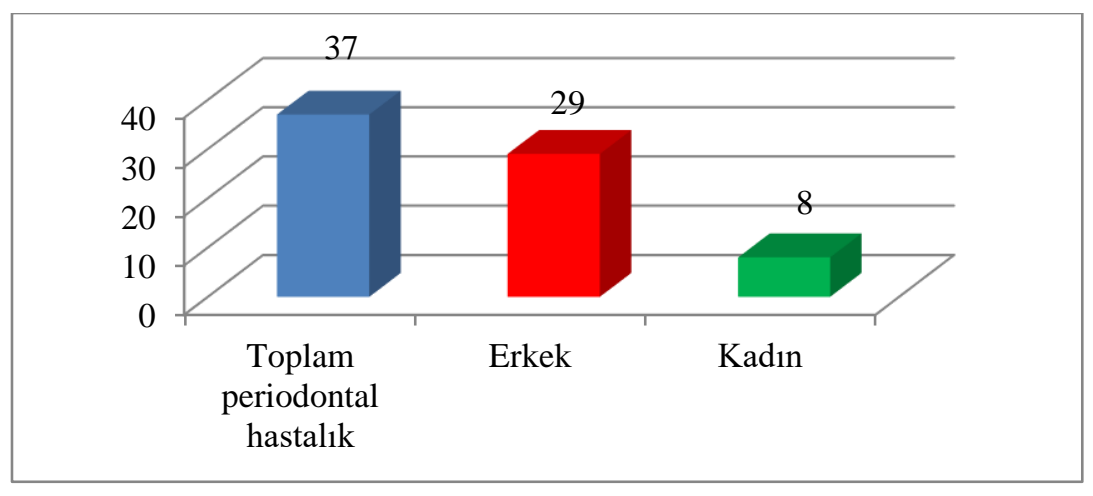

Grafik 2. Periodontal hastalığın cinsiyete göre dağılımı.

Yapılan muayene sonucunda 71 sporcudan 3'ünde toplam 7 ön (anterior) bölge diş kırı̆g (fraktür) teşhis edildi. Diş kırığının oluşma şekli sorgulandı̆̆ında; bir sporcuda antrenman sırasında ve iki sporcuda günlük faaliyet sırasında olduğu belirlendi. Tüm sporcuların muayenesi sonucunda, 71 sporcunun 67'sinde diş ve dişeti hastalıkları teşhis edilirken, 67 sporcunun 37'sinde de sadece dişeti hastalığı olduğu teşhis edildi. Sporcular Tempora Mandibuler Eklem (TME) rahatsızlığı açısından değerlendirildiğinde, 1 sporcuda tek taraflı sağ TME ve 2 sporcuda çift taraflı TME rahatsızlığı yapılan muayene ile teşhis edildi. 1 sporcuda, 20 yaş diş çevre doku enfeksiyonu "akut pericoronitis" görüldü. Tüm sporcuların servikal ve submandibuler lenf muayeneleri normaldi ve hiçbir sporcunun ağız-diş ve çevre dokularını korumak amaçlı olarak ağız koruyucu kullanmadığı belirlendi.

Sporcuların oral hijyen yeterliliği değerlendirildiği zaman; diş firçalama alışkanlığının 43 sporcuda her gün, 18 sporcuda 2-3 günde, 6 sporcuda haftada, 2 sporcuda ayda, 2 sporcuda da hiç olmadığı kısa anket sorgulaması ile öğrenildi (Grafik 3). 


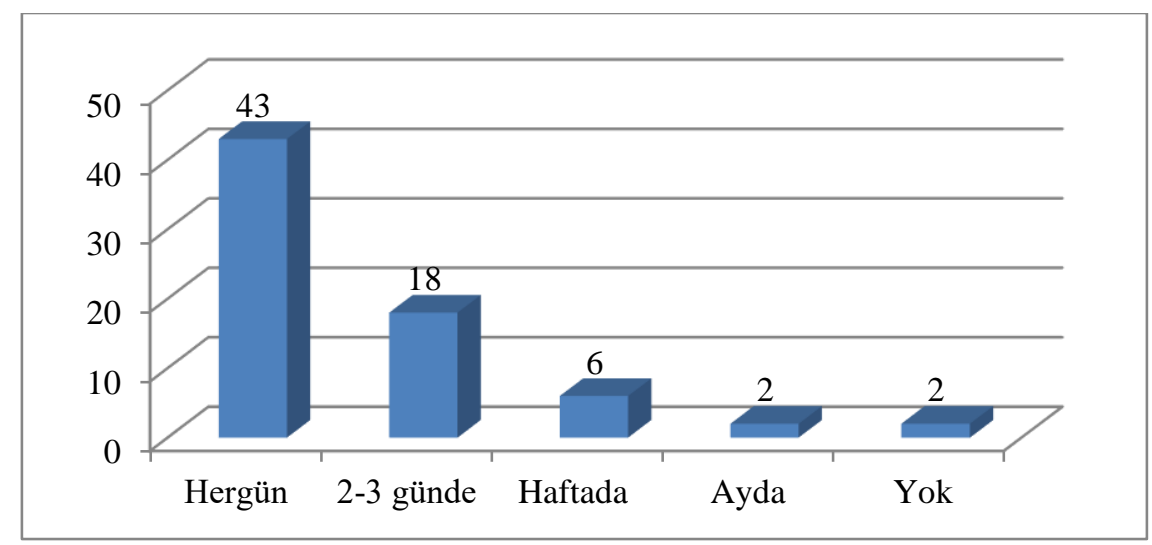

Grafik 3. Sporcuların oral hijyen alışkanlığı (diş firçalama alışkanlığı).

Yine sporcu grubunda bugüne kadar diş hekimine gitme sıklı̆̆ı sorgulandığında; 16 sporcunun 10'dan fazla, 24 sporcunun 5-10 arasında, 19 sporcunun 3-5 arasinda, 9 sporcunun sadece 1 kez diş hekimine gittiği, 3 sporcunun bu güne kadar hiç diş hekimine gitmediği verilen cevaplar ile ortaya çıktı (Grafik 4).

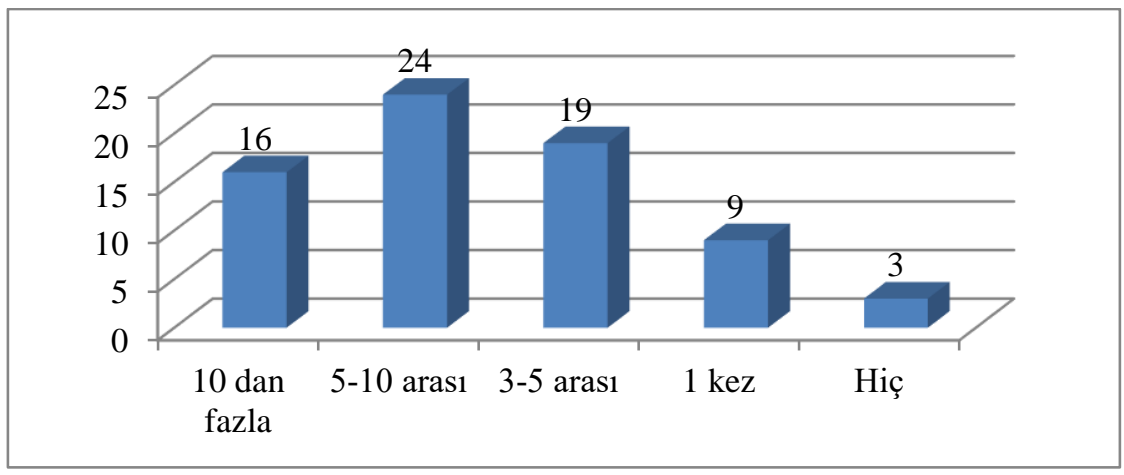

Grafik 4. Sporcuların bugüne kadar diş hekimine gitme sıklığı. 


\section{TARTIŞMA VE SONUÇ}

Engelli sporculara uygulanacak diş ve dişeti tedavileri hasta-hekim işbirliği, uyumu (kooperasyon) problemleri sebebiyle güçlük göstermektedir. Diş tedavisi gerektiren sporcularda başarıyı etkileyen problemlerden biri hasta olarak uyumluluğudur. Bu sebeple yapılan araştırmalar sonucunda, engelli bireylerde tedavi edilmemiş diş hastalıklarının, sağlıklı bireylere göre yüksek olduğu vurgulanmıştır. Sporcuların, sporcu olmayan bireylere göre beslenme programlarında farklılıklar vardır. Bunlardan en önemlisi, karbonhidrat alımının sporcu bireylerde daha yüksek olmasıdır. Ayrıca engelli sporcularda, engelliliğin türüne göre kas ve eklem problemlerine bağlı ve görme probleminin olumsuzlukları, oral-hijyen eksikliğinin ortaya çıkma sebebi sayılabilir.

Duyma engelli bireylerde çürük oluşumu engelli olmayan bireylere göre daha hızl gelişir. Yaş aralığı 6-12 olan 236 birey ile yapılan çalışmada, işitme engelli bireylerde çürük görülme oranının \% 30,5 (erkek \% 16,5 - kadın \% 14) olduğu bildirilmiştir. Aynı araştırmacılar, engelli olmayan aynı yaş grubu için çürük görülme oranını da \% 15,8 (erkek \% 8,8-kadın \% 7) olduğunu tespit etmişlerdir (Kar ve ark., 2016).

Delhi ve Gurgaon bölgesinde bulunan işitme engelli özel okulda yapılan farklı bir çalışmada ise çürük sıklığının \% 72,4 olduğu bildirilmiştir (Avasthi, Bansal, Mittal ve Marwaha, 2011). Farklı bir çalışmada DSÖ kriterleri kullanılarak Güney Hindistan'da 7-17 yaş aralığına sahip işitme engelli bireylerde yapılmıştır. Çalışmada sonucunda araştırmacılar, bireylerin sosyal durumlarına bağlı olarak çürük sıklık oranının arttığını ve bu oranın $\% 89,1$ oranına yükseldiğini görmüşlerdir(Reddy, Chaurasia, Bhambal, Moon ve Reddy, 2013). 2014 yllinda yapılan bir çalışmada ise araştırmacılar engellilik şeklinin çürük gelişimi için farklılık oluşturmadığını bildirmişlerdir. Araştırmacılar, aynı çalışmada işitme engelli bireylerin çürük sıklığı ile görme engelli bireylerin çürük sıklığı arasında fark görülmediğini ve işitsel engelli bireylerde periodontal hastalık oranının düşük olduğunu görmüşlerdir (Bimstein, Jerrell, Weaver ve Dailey, 2014). Bizim çalışmamızda 3 sporcuda diş hastalığı görülmüş olup, işitme engelli sporcu çürük sıklığı \% 27,8 (erkek \% 9,1 - kadın \% 18,2), periodontal hastalık \% 36,4 oranında bulunmuştur. Bu değer, diğer işitme engelli bireylerle yapılmış olan çalışmalarda bulunan sonuçlardan düşüktür. Bunun sebebi olarak sosyo-ekonomik gelişmişliğin yanında sporculara verilen oral-hijyen eğitiminin sonuçları düşünülmüştür. 
Görme engelli bireylerin ağız-diş ve periodontal sağlığının, engelli olmayan bireylere göre daha kötü olduğu çalışmalarla rapor edilmiştir (Reddy ve Sharma, 2011). Görme engelli bireylerin çürük sıklığının, farklı engelli bireyler ile herhangi bir farklılığına sahip olmadığı da çalışma ile bildirilmiştir. Aynı çalışmada periodontal doku hastalık ve diştaşı oluşumunun görme engelli bireylerde yüksek olduğu görülmüştür (Bimstein ve ark, 2014). Ülkemizde 5-14 yaş aralığına sahip 74 görme engelli bireyler ile yapılan çalışmada, araştırmacılar katılımcıların \% 35,1'inde diş hastalıkları görmüşler ve DMF-T değerini 3.2 olarak bulmuşlardır (Açıl ve Ayaz, 2013). Farklı bir çalışmada, 6-18 yaş arasındaki 167 görme engelli bireyin periodontal skorlarının yüksek çıktığı bildirilmiştir. Bu yaş aralığında olan katılımcılardan 9-11 ve 12-14 yaş aralığına sahip bireylerde periodontal skorların daha da yüksek olduğu araştırmacılar tarafindan vurgulanmıştır (Jain, Gupta, Aggarwal ve Goyal, 2013).

Bizim çalışmamızda 11 görme engelli sporcuda (erkek 11 - kadın 0) diş hastalığ 1 rastlanmış ve Ç.P.D \% 64,7 - DMFT değeri de 2,8 olarak bulunmuştur. Çalışmamız yapılmış olan çalışmalarla değerlendirildiğinde, DMFT değerinin çalışmaya katılan sporcularda çok azda olsa düşük olmasının yanında, çürük sıklık değerindeki yükseklik dikkat çekiciydi. Periodontal hastalık açısından değerlendirdiğimizde ise sporcu grubunun \% 59'da (erkek 10 - kadın 0) dişeti hastalığ1 belirlendi. Diş ve dişeti hastalıklarının, ara ögün yeme alışkanlığı ve sonrasında yetersiz ağız bakımı ile arttığı bilinmektedir. Nitekim, sporcu grubunun yeme alışkanlıklarının araştırılması ve oral-hijyen eğitiminin arttırılmasının önlem alıcı ilk tedbir oluşturabileceği düşünüldü.

Ortopedik engelli sporcuların ağız-diş bakımları, işitme ve görme engelli sporculara göre güç olmaktadır. Ülkemizde yapılan çalışmada, 52 katılımcıdan 15 'inde (\% 29,7) diş hastalığ 1 belirlemiştir (Sarı ve ark., 2012). Hindistan'da 150 ortopedik engelli ile yapılan çalışmada, katılımcıların periodontal skorlarının yüksek olduğu ve hijyen yetersizliğinin diğer engelli gruplara göre arttığı ve bunun sebebi olarak, el kullanım becerilerinin yetersizliği rapor edilmiştir (Ameer ve ark., 2012). Çalışmamızda ortopedik engelli 43 sporcunun, 19'unda (erkek 12 - kadın 7) diş hastalığı belirlendi. Grubun DMFT indeks değeri 5,0 ve Ç.P.D. \% 44,2'i olarak bulundu. Diş hastalı̆̆ının yüksek olmasına rağmen, sporcularının tedaviye yönelimleri yüksekti $(\% 60,5)$. Dişeti hastalığının grupta görülme yüzdesi \% 53,5'ti (erkek 18, \% 41,9 - kadın 5, \% 11,7). Ortopedik engelli sporcu grubu kendi içinde engellilikleri çeşitlilik gösteren bir grup olup, çalışmamızda engelliliğin hangi ekstremiteyi içerdiği belirtilmemiştir. 
Tüm sporcu grubunun tek tek değerlendirmeleri tarafımızdan yapıldığında, önceki çalışmalarla tutarlılık ortaya çıkmıştır. Bu çalışmaya kadar günümüzde engelli sporcular üzerinde bir çalışma yapılmamıştır. Hatta yapılmış olan çalışmaların neredeyse tamamı 7-17 yaş aralığına sahip engelli bireylerden oluşmuştur. Çalışmamız, önceki çalışmaların sahip olduğu sosyoekonomik ve kültürel yapısının üzerinde olan katılımcı grubunu içermiştir. Bu sebeple ortaya çıan sonuçlar sporcu olmasalar dahi önceki katılımcı grupların değerlerinden daha düşük bulundu.

Sonuç olarak, engelli sporcuların ağız-diş sağlığının koruması ve bakımı önemli bir yer tutmaktadır. Sporcuların beslenme özellikleri ağız-diş sağlığının korunması için artı tedbirlerin alınmasını ortaya koymaktadır. Engelli sporcularda kötü ağız-diş sağlı̆̆ının genel sağlık ve sportif performansa olumsuz etkisini önlemek için, koruyucu ve tedavi edici programlar arttırılmalıdır.

\section{KAYNAKLAR}

Aç1l, D. \& Ayaz, S. (2015). Screening of Visually Impaired Children for Health Problems. Asian Nursing Research, 9(4), 285-290.

Aggerryd, T. (1983). Goals for oral health in the year 2000: cooperation between WHO, FDI and the National Dental Association. International Dental Journal, 33, 55-59.

Almerich-Silla, J.M. \& Montiel-Company, J.M. (2007). Influence of immigration and other factors on caries in 12 and 15 year old children. European Journal of Oral Sciences, 115(5), 378-383.

Altun, C, Güven, G, Başak, F, et al. (2005). Six to eleven age groups are evaluated in terms of mouth-teeth. Gülhane Tip Dergisi, 47, 114-118.

Ameer, N. Palaparthi, R, Neerudu, M, Palakuru, S.K, Singam H.R., Durvasula, S., \& et al. (2012). Oral hygiene and periodontal status of teenagers with special needs in the district of Nalgonda, India. Journal of Indian Society of Periodontology, 16, 421-425.

Avasthi, K, Bansal, K, Mittal, M, \& Marwaha, M. (2011). Oral health status among Delhi and Gurgoan sensory handicapped children. International Journal of Clinical Dentistry, 3, 21-23.

Bimstein E., Jerrell, R.G., Weaver, J.P., \& Dailey, L. (2014). Oral characteristics of children with visual or auditory impairments. Pediatric Dentistry, 36(4), 336-341.

Doğan, G.B., \& Gökalp, S. (2008). Situation and Treatment Need of Tooth Decay in Turkey, 2004. Hacettepe Üniversitesi Diş Hekimliği Fakültesi Dergisi, 32(2), 45-57.

Gay-Escoda, C., Vieira-Duarte-Pereira D.M., Ardèvol J., Pruna R., Fernandez J., \& Valmaseda-Castellón e. (2011). Study of the effect of oral health on physical condition of professional soccer players of the Football Club Barcelona. Medicina Oral, Patología Oral y Cirugía Bucal., 16(3), 436-9.

Jain, A., Gupta, J., Aggarwal, V., \& Goyal, C. (2013). To evaluate the comparative status of oral health practices, oral hygiene and periodontal status amongst visually impaired and sighted students. Special Care in Dentistry, 33(2), 78-84.

Kar, S,. Kundu, G,. Maiti, SK,. Ghosh, C., Bazmi, BA., \& Mukhopadhyay, S. (2016). A comparative evaluation of dental caries status among hearing-impaired and normal children of malda, West Bengal, evaluated with the caries 
assessment spectrum and treatment. Journal of Indian Society of Pedodontics and Preventive Dentistry, 34(4), 3069.

Kinane, D.F. \& Attstrom, R. (2005). European Workshop in Periodontology group B. Advances in the pathogenesis of periodontitis. Group B consensus report of the fifth European Workshop in Periodontology. Journal of Clinical Periodontology, 32, 130-131.

Koser, C. \& Nalçac1, A. (2011). Approaches to caries prevalence and concept of karyogram. Cumhuriyet Dental Journal, $14(3), 230-245$.

Külekçi, G. \& Gökbuget, A. (2009). The Effect of Oral Microbiota on General Health. ANKEM Dergisi, 23(3), $137-145$.

Linea, C. \& Former, L. (2008). Diatery habits in a child population to caries experience. Caries Research, 42(5), $387-393$.

Naidoo, S. \& Myburgh, N. (2007). Nutrition, oral health and the young child. Maternal \& Child Nutrition, 3(4), $312-421$.

Reddy, V.K. \& Sharma, A. (2011). Prevalence of oral health status in visually impaired children. Journal of Indian Society of Pedodontics and Preventive Dentistry, 29,25-27.

Reddy, V.K. Chaurasia, K., Bhambal, A,. Moon, N,. \& Reddy, E.K. (2013). A comparison of oral hygiene status and dental caries experience among institutionalized visually impaired and hearing impaired children of age between 7 and 17 years in central India. Journal of Indian Society of Pedodontics and Preventive Dentistry, 31, 141-145.

Saraçoğlu, A,. Kümbüloğlu, Ö., Hatipoğlu, H.A., \& User, A. (2007). Relationship between social statüs, caries and periodontal disorder prevalence in dental students (an epidemiological study). Cumhuriyet Üniversitesi Diş Hekimliği Fakültesi Dergisi, 10(1), 10-15.

Sarı, E.M,. Özmen, B., Koyuturk, A.E., ve Tokay, U. (2012). Assessment of children with physical disabilities in terms of mouth and dental health. Atatürk Üniversitesi Diş Hekimliği Fakültesi Dergisi, 22(1), 7-13.

Slots, J. (2002). Selection of antimicrobial agents in periodontal therapy. Journal of Periodontal Researchs. 37(5), 389398.

Susan, A.F.O,. Stuart, A.G,. Larry J.P., Weintraub, J.A., Soobader, J.M., Bramlett, M.D., \& Newacheck, P.W. (2007). Influences on Children's Oral Health: A Conceptual Model. Pedia, 120(3), 26-43.

Şahin, S., Saygun, I., Enhoş, Ş., Akyol, M., Alyuğ, A., ve Tekbaş, Ö.F. (2009). Evaluation of the effect of education level on oral health in young adult males. Gazi Üniversitesi Diş Hekimliği Fakültesi Dergisi, 26(3), 133-139.

Tieri, M., Martinelli, D., \& Tripodi, D. (2016). The effect of swimming on oral health status: competitive versus noncompetitive athletes. Journal of Applied Oral Science. 24(2), 107-3.

Ünlü, N., Şener, S., \& Karabekiroğlu, S. (2014). Frequency of caries in first molar teeth and relationship with oral care factors in young adults. Selcuk Dental Journal, 1, 14-19. 